\title{
Scientific Attitude and Picture Language. Otto Neurath on Visualisation in Social Sciences*
}

\author{
Elisabeth Nemeth, Vienna
}

\begin{abstract}
I have heard with great interest about the latest developments in relativity theory which can be traced to your conception that gravity as a function depends on the total distribution of mass and remains constant toward certain transformations (for example, rotation). It was this idea in your Mechanics which has never left me since my first reading, and has influenced my own intellectual development and by indirect paths even economics itself. It was your tendency to derive the meaning of particulars from the whole rather than the meaning of the whole from a summation of the particulars, which has been so important. It is in value theory in particular that these impulses have benefited me through indirect paths. ${ }^{1}$
\end{abstract}

These lines are taken from an undated letter from the front which Otto Neurath wrote to Ernst Mach, probably in 1915. Although serving as an officer in Galicia at the time, he was evidently resolved not to lose sight of his scientific career as an economist and, indeed, to advance it as far as possible. It was probably not long after writing this letter that he suggested to the War Ministry that a research post be set up and commissioned to document the experiences of the war economy for subsequent research work. The Ministry took up the proposal and put Neurath in charge of the post. ${ }^{2}$

In 1917 he obtained his habilitation in political economy at the University of Heidelberg, thereby establishing himself as an expert on 'state-run economic systems', as the title of his habilitation lecture: economy in kind, war economy, planned economy. This specialisation was certainly in keeping with his work before the war, albeit with an emphasis due primarily to developments during the war. Indeed prior to 1914 Neurath's studies of the theory of war economy was only one facet of a complete scientific ouvre remark- 
able for its extraordinary breadth. It ranged from works on the sociology of religion in the Balkan states to banking and finance under the Monarchy, the impact of state interventions on pricing, and the history of optics, without forgetting philosophy. For Neurath, at the core of it all was nothing less than a new theoretical foundation of economics that would make it possible to bring together, in a fruitful way, the two main adversaries of the time: the historical school of national economy, with its empirical orientation and its view of national economies as entities on the one hand, and the Austrian school with its mathematical methods and its emphasis on the individual appreciation of commodities as the basis of the value theory on the other. ${ }^{3}$ In his letter to Mach Neurath alludes to this highly ambitious project, a project on which he had already begun to elaborate around 1910 in a number of writings on the theory of social sciences and the value theory, and which he had also presented in his contributions to the debates on methods an values at the Social Policy Association. ${ }^{4}$

It will suffice, for our purposes, to sketch out Neurath's project in a few broad outlines. Given that his economic theories were long considered absolutely abstruse and that, to this day, his terminology requires a degree of familiarisation, it should be said that his economic approaches have proved more robust - to use a contemporary buzzword - than could ever have been thought. Since the 1990s they have been the subject of serious consideration in ecological economics; his contributions have also re-emerged in welfare and development economics and are now being discussed again in the context of Amartya Sen's capability approach. ${ }^{5}$

In one of his most important essays on the value theory ${ }^{6}$ Neurath advocated adopting 'wealth' as the subject matter of national economy, thus reviving a tradition that stretches from Aristotle to Adam Smith. Neurath believed that in spite of its venerable roots it was a tradition that had virtually disappeared from modern theory, to his mind quite wrongly.

In referring to wealth as the subject matter of national economy we are concurring with an ancient tradition. By wealth we mean the totality of pleasure and displeasure to be found in individuals and groups of individuals. The term pleasure, according to our usage, has the advantage of embracing both complex and primitive facts simultaneously. ${ }^{7}$ 
In Neurath's view, the fact that economists have concentrated on the logic of exchange circumstances under market conditions, as represented in the unity of money, has all too narrowed the economic view. He felt that the price theory was often treated as if prices were an accurate representation of wealth. Admittedly, there are also ideological reasons for this constricted view: 'The classical school of economics has examined one unique form of such systems of organisation, free competition, and it has praised it just like the mercantilists praised theirs. ${ }^{8}$ But according to Neurath, the influence of an anachronistic science ideal was more important for such a restriction. And while such an ideal - the mechanistic - had long since been overcome in the natural sciences, it was very much alive and well in monetary and price theory. It re-emerges here as the ideal of the calculability of economic value with the aid of a single unit.

When Neurath defines wealth as the 'totality of pleasure and displeasure to be found in individuals and groups of individuals', it is not because he wishes to introduce a unit of measurement other than the monetary. Rather, he proposes a terminology that prevents us from looking for a unit in the first place that might serve as the basis for calculating the welfare of individuals or groups. Neurath justifies the terminological decision in favour of 'pleasure' with the fact that the term 'in our usage embraces both complex and primitive facts to an equal degree'. The expression does not readily suggest that we search for an element that might serve as a unit of measurement for the whole. Accordingly, in Neurath's wealth theory, 'pleasure' and 'displeasure' include elements as different as: the pleasure and displeasure afforded us by good/bad food; living conditions; clothing; good or bad working conditions; access to education or exclusion from it; but also the enjoyment to be gained from a professional or leisure activity; satisfaction through social recognition; access to culture such as theatre, music and museums; involvement in public life; etc. From 1917 Neurath refers to this constellation of different elements as the 'life circumstance', and it is with this conceptual understanding that his approach is now once again being discussed..$^{9}$

As Neurath says, the approach aimed at conceiving of wealth as composed of fundamentally different types of elements is based on a decision. It consists in introducing 'wealth as a comparable quantity, albeit one that is not measurable ${ }^{10}$. Even under this prerequisite the wealth of individuals and groups can be studied accurately, according to Neurath. True, we need to use more developed mathematical models than a calculus which captures a complex by reducing 
its elements to a unit of measurement. According to Neurath, it is the modern methods of relational calculus that will enable economists to compare systematically different constellations of dissimilar elements of wealth.

Neurath was aware that this comparative approach poses immense problems of methodology. And he realised that the question of selecting the right methods for assessing these heterogeneous constellations was of the utmost methodological importance. So what were in his view, in 1911, suitable means for representing and systematically comparing such heterogeneous constellations: curves? formulæ? tables? In Neurath's view neither curves nor formulæ are suitable for grasping the problems that are involved here. For Neurath, geometric representations are often detrimental to scientific analyses: because of them, one 'all too easily transfers to the substrate characteristics that pertain to the geometric figures rather than to the substrate which they represent'. $\mathrm{He}$ added that geometric representation easily leads to 'using simple curves and to neglect cases that might for instance require isolated dots for the representation'. ${ }^{11}$ They were also an invitation 'to formulate all problems in such a way that only two or at most three variables occur in each case'. ${ }^{12}$

Neurath was also of the view that efforts to express observed connections using formulæ can easily be misleading. Indeed, 'formulæ are particularly apposite in cases where one approximately knows the nature of a connection, even if its details are unknown. ${ }^{13}$ And in the area Neurath is concerned with, that is precisely not the case. He is therefore in favour of using the much older table form. Why? - Because tables allow us first of all to describe complexes that are still unknown to us. Even in cases where a great deal remains undetermined, they allow us to achieve clarity and

to monitor simultaneous changes of entire constellations. [...] In investigations such as those practice demands, one is required to look into complexes that are entirely unknown to one and which one must first describe. The table form makes it possible to follow separately the variations of each individual combination in a clearly structured way. [...] Tabular representation allows random indeterminacy; gaps can be noted; etc. In such indeterminate cases geometric representation fails completely as one cannot very well draw an 'indeterminate' curve that may prove to be a series of isolated points. If one renders the theoretical representation and the concrete description in table form, one has the great advantage that one can carry out all the transitions from the most general to the most specific analyses in an analogue form. ${ }^{14}$ 
The two terms 'describe' and 'variation' are key concepts in Ernst Mach's epistemology, and it is no coincidence that they should occur at precisely this point in Neurath. Let us remind ourselves of the letter to Ernst Mach mentioned at the outset, a letter in which Neurath links his ideas in the field of economics with Mach's The Science of Mechanics. At this point I would like to say a few words - very briefly-about Mach. ${ }^{15}$ In his Science of Mechanicsindeed in precisely the place to which Neurath alluded in his letter with his reference to the theory of relativity - Ernst Mach suspended, as it were, the classic formula of the law of inertia because he believed that the nature of the connection as formulated by the law had to be rethought. His famous studies of Newton's terminology (in particular the way in which Newton introduced the concept of absolute space and absolute time) ultimately led Mach to propose a new formulation in which gravitation appears as a function of the entire mass distribution of the universe. In this critical reconstruction of key elements of Newtonian physics Mach himself saw only one example of something far more general. Something he did not tire of highlighting as an essential-perhaps even the essential - momentum of scientific progress: namely the dissolution of concepts which, to contemporary research, appear as established once and for all. Mach believed that it had to be shown time and time again that even the most firmly established concepts were merely auxiliary constructs that served to do nothing other than give a provisional account of relations extant between our experiences. And while such auxiliary constructs cannot be dispensed with - whether in our everyday lives or in science - we do tend to forget that we were the ones who introduced our concepts - as auxiliary constructs that help to give an account of the relations between our experiences. Lest we forget this, Mach demands that we should also keep dissolving the most firmly established concepts and formulæ (particularly those) so that we do not perceive them as something independent of ourselves and allow them to become obstacles to our knowledge.

That is precisely the context in which Mach sees research into the history of science as an essential part of natural science itself. And it is also the context in which he explains what his theory of elements is about. No researcher, says Mach, can detach himself from historical developments; he always builds on findings already acquired, correcting them here and there, following them up elsewhere, and 'also adding his own errors, often unnoticed, to those of his predecessors and contemporaries' ${ }^{16}$ Such errors are due not least to the fact that 'it was very much a matter of chance, of practical need, of earlier inves- 
tigations, as to which elements emerged as the more important, which ones received the attention, and which ones remained unheeded'. ${ }^{17}$ We cannot undo the path, writes Mach, the attention of past researchers has taken in history, nor would it be desirable to do so. For even if we were to succeed in returning to 'the entirely naive standpoint', it would offer the advantage of unconditionality, but also its disadvantage: namely 'the confusion resulting from the complication of the task and the impossibility of beginning an investigation'. ${ }^{18}$ The steps backwards into the past which Mach has in mind are of a different type. They should not lead us to a primitive standpoint, but to something which Mach calls 'artificial naivety'. A resolution into Machian 'elements' is conceivable only from the starting point of a high level of scientific thinking:

So if today we appear to return to a primitive standpoint in order to conduct anew the research by better routes, it is an artificial naivety that does not surrender the advantages gained over a long cultural journey, but on the contrary uses insights which presuppose a fairly high level of physical, physiological and psychological thinking. It is only on such a level that a resolution in 'elements' is conceivable. It is about a return to the starting points of research with the deeper and richer insight brought about precisely by the research that went before. ${ }^{19}$

It is my contention that, with his extremely broad definition of the wealth of individuals and groups, Neurath was seeking to adopt such a standpoint of 'artificial naivety' for the field of economics. By using different, nonmutually derivable elements as determinations of the phenomenon of wealth (and poverty), he introduced to economics an approach analogous to that of Mach in the fields of physics, physiology and psychology. Mach stressed the fact that-contrary to a common misconception - his theory of elements was not about finding some ultimate units which definitively could not be broken down any further. Rather, it was a matter of starting from complex findings and breaking them down into 'elements that cannot currently be broken down any further'. ${ }^{20}$ The elements repeatedly listed by Mach by way of example - 'colours, tones, pressures, heat, odours, spaces, times, etc.' - clearly show that he meant largely to invalidate the traditional classifications for physical, physiological and psychological objects. It is not for nothing that most philosophers regarded Mach's elements as nothing other than a mishmash from which they 
turned away in disgust. Neurath did not fare much better with his wealth elements: they are just as confusingly heterogeneous as Mach's elements.

It is important to see that, for Mach and Neurath, the willingness to adopt such an artificially naïve approach represents an essential moment in the scientific attitude. The value of that approach is not motivated morally (e. g. as a virtue of personal modesty), but epistemologically: the scientist needs such an approach if he (or she) is not to succumb to the seductive power of extant concepts. ${ }^{21}$

The key link with Neurath's 'Visual Education' is precisely here. In a lengthy text written in the last few years of his life titled 'Visual Education. Humanization versus Popularisation' (published in 1995) Neurath differentiated what picture language was meant to achieve from what he referred to as the 'popularisation' of knowledge:

Generally speaking, on an average, books destined for children and the man in the street $[\ldots]$ try to simplify the highest level of scientific formulation, presented in scientific books. Sometimes writers think that a translation of well-selected terms into popular terms is sufficient, whereas it is common knowledge that the insufficiency of these terms was the main reason for the introduction of scientific terms. This kind of translating from the complicated to the simple, from top to bottom, as it were, we shall call Popularisation of knowledge. ${ }^{22}$

Let us focus on what, from Neurath's point of view, is problematic about popularisation. According to Neurath, the main reason for introducing scientific terms was that everyday language often proved inadequate when it came to formulating certain complex issues and their connections as precisely as scientists require. The popularisation that seeks to dumb down, as it were, the artificial language of science must therefore be misleading. So when Neurath speaks out against the top-down strategy of popularisation in favour of a bottom-up strategy and refers to it as the 'humanisation' of knowledge, it would be a mistake to consider everyday language as such as the starting point (i. e. the 'bottom'). The terms used in both scientific and everyday language mislead us towards the uncontrolled use of terms handed down to us. In both cases the strategy of choice - for both Neurath and Mach - is 'artificial naivety', which is deliberately aimed at perceiving our terms as sets of heterogeneous elements whose relations to one another we need to describe. 
There are many people who become uneasy when confronted with a general term like 'magnetism' but who would not be irritated by a heading like 'magnetic and magnets and iron'. Why should we not start with the pupil's own realm and his own tools for expression and analysis? 'Electricity' is not a term to be used at a lower stage. By speaking of some piece of glass being 'electric' if it behaves in a certain way, and of such simple observation-statements, one avoids the misleading questions 'what is electricity', 'what is gravity', 'what is life'? If we speak of living bodies when they behave in a certain way, we can go on to describe a virus, which is sometimes crystallised, sometimes propagating etc. ${ }^{23}$

Let us now turn to Neurath's pictograms. They have been somewhat rediscovered and reappreciated in recent years. ${ }^{24} \mathrm{I}$ would like to begin my thoughts on Neurath's picture language with a passage which occurs several times in Neurath's writings and which has often been cited in recent years. In my opinion it has been thoroughly misunderstood time and time again. According to Neurath, it is important for the 'teaching-picture' that it is created according to the following method: 'At the first look you see the most important points, at the second, the less important points, at the third, the details, at the fourth, nothing more - if you see more, the teaching-picture is bad.' 25

The misunderstanding about this passage, which I intend to repudiate in the following, consists in assuming that the criterion of a successful visualisation according to Neurath lies in the speed with which its content can be grasped. From that point of view one would have to deduce from Neurath's remarks quoted above that the - perhaps unattainable - ideal case would be one where the visualised contents are grasped instantly, i. e. at a glance. The second and third glance would be nothing other than necessary evils, to be minimised of course; and in the case of a particularly successful visualisation they might not even be necessary. Frank Hartmann appears to be saying precisely that when, following the quotation, he explicitly writes: 'A statement has to be recognisable at first glance. ${ }^{26}$ And by way of example Hartmann cites a passer-by who also comes up in Neurath: he has little time and is able, en passant as it were, 'to roughly take in the information in passing'.

This fictional passer-by is an important indication of where-I believethe misunderstanding comes from. The pictograms used by Neurath began to take the world by storm in the 1930s, notably as symbols used for orientation purposes in public spaces and in our everyday world (operating instructions). 
To this day we live with the 'talking pictures' designed for the most part by Gerd Arntz and to the dissemination of which Neurath contributed a great deal in his countless publications. (See picture 1 and picture 2.)

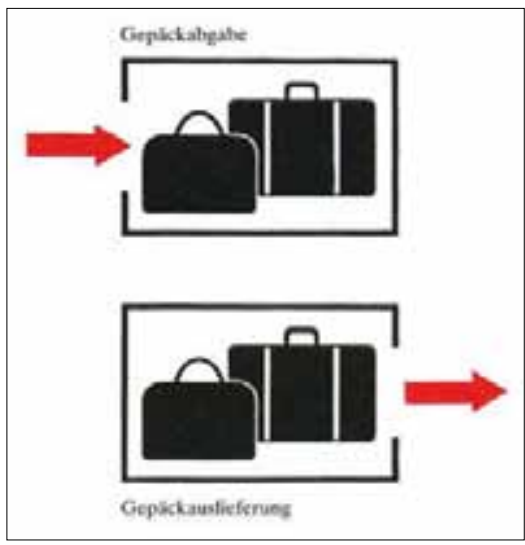

Picture 1.

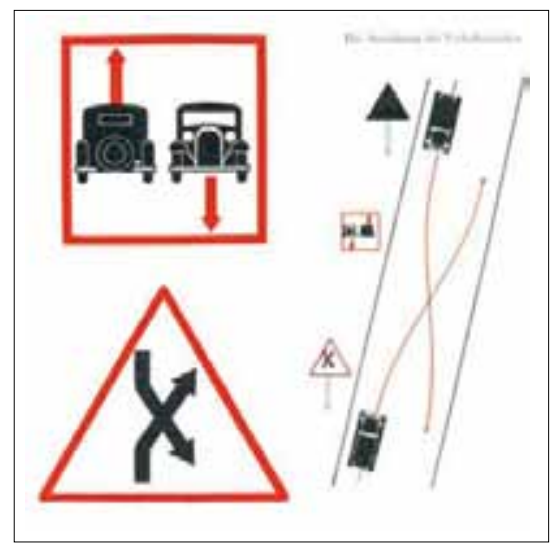

Picture 2.

So Neurath accurately recognised the role of these pictures in guidance systems for public spaces and assessed their future significance quite correctly. That includes presenting information so that it can be grasped as quickly as possible. However this function must not be confused with the method's intended purpose, for which Marie Neurath, Otto's third wife, invented the name Isotype ('International System of Typographic Picture Education'). The name designates the main methodological principle through which the Vienna method differs from other visualisation methods. It does so by combining the two Greek words 'isos' (equal) and 'typos' (character). Differences in the size of quantities are to be represented by the juxtaposition of pictorial characters of the same shape and size - rather than by pictorial characters of different sizes. The most famous example from the Vienna period features the long queues of the unemployed (see picture 3). Neurath further illustrated the point of the Vienna Method of Pictorial Statistics (the older name for the ISOTYPE method) by comparing it with examples of poor visualisation (see pictures 4 and 5 overleaf). Similarly analogous references to poor visualisation can also be found in today's publications on the theory of visualisation (see picture 6$).{ }^{27}$ 


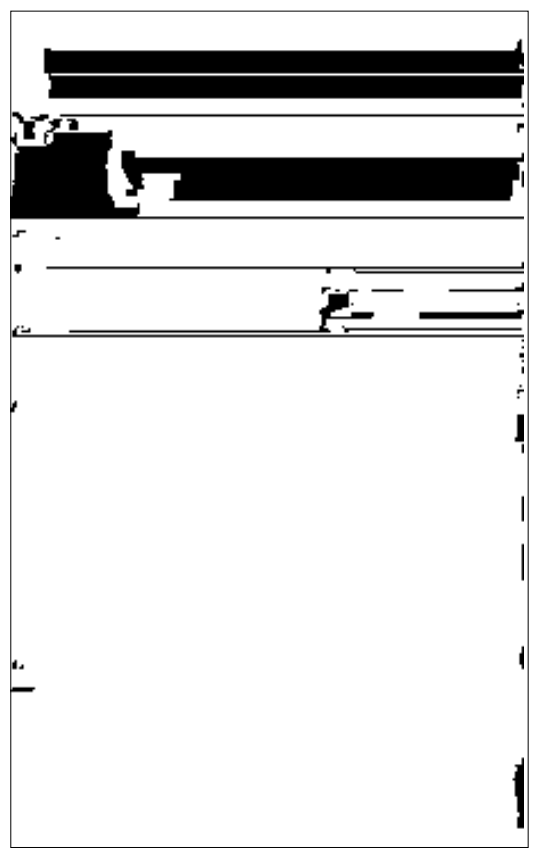

Picture 3.

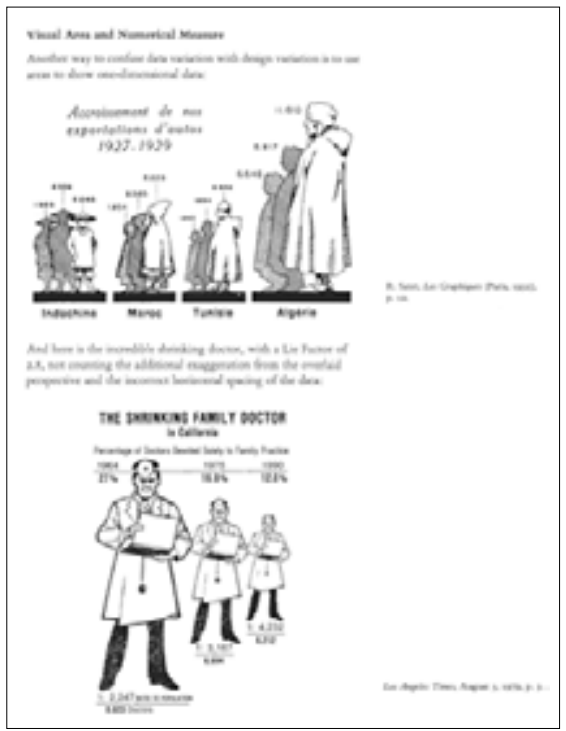

Picture 4.

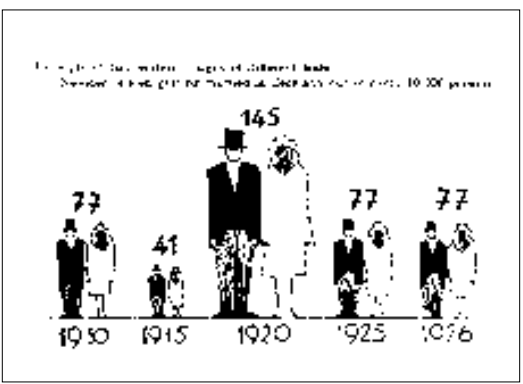

Picture 5.

Picture 6. 
Picture 7.

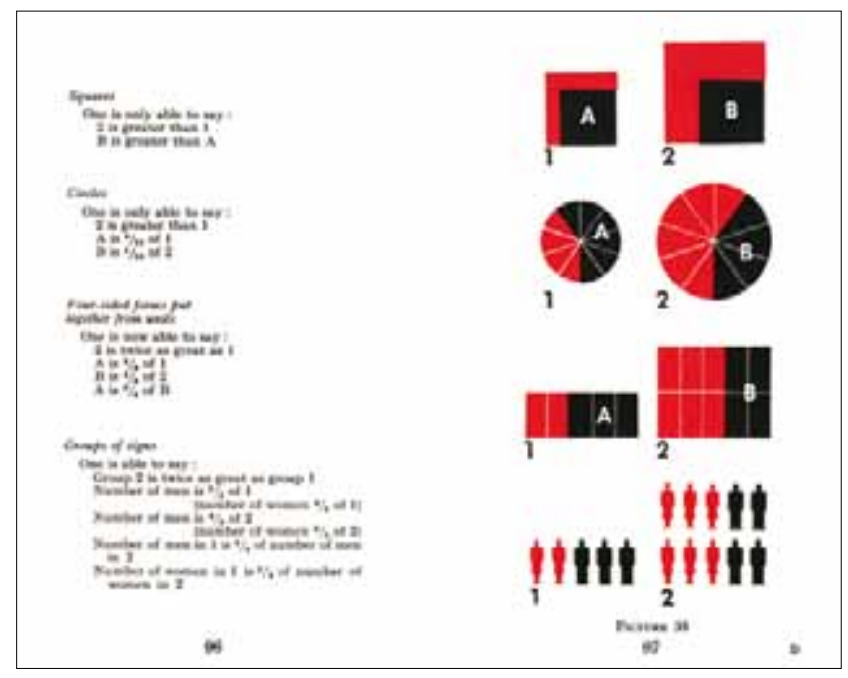

What is particularly interesting in our context is the way in which Neurath explained the main advantages of the methodological principle in Isotype. Here-in picture 7-Neurath shows us four different ways of visualising quantitative data: squares, circles, rectangles, and groups of figures. In all four cases sets are related to one another, specifically sets 1 and 2, and sets A and B, with $A$ as a subset of 1 , and $B$ as a subset of 2 . Neurath then strikingly demonstrates that the visualisation method used in each case determines how much the observer finds out about the size ratios. In the first case (the representation using squares) we can only determine the absolute size differences between $\mathrm{A}$ and $\mathrm{B}$ and between 1 and 2. The circles (example 2) already contain more information: with the help of the segments we can determine quantitatively the ratio of subsets $A$ and $B$ in relation to each of the total sets 1 and 2 . Admittedly, the comparison between sets 1 and 2 (between the two circles) is limited to ascertaining an absolute difference in size. If we now consider the rectangles consisting of units (example 3), we can also work out for the first time the quantitative relation between set 1 and set 2 . Finally the fourth case (groups of figures) is different from the others. Here it is not about the information on the set ratios being more abundant. The benefit is on another level, namely the memory level: we directly perceive which objects are involved and are therefore also better able to remember what objects were involved. 
So a key aspect is that Neurath's visualisation method is not about representing a statement in such a way that it can be perceived at a single glance. Indeed, Neurath constructs his charts in such a way that it is impossible to grasp what they have to say at one glance. That is probably also the reason why the Isotype method is virtually never used in today's newspapers and why pie charts dominate instead. This phenomenon is not down to the fact that the Isotype method has been forgotten. The graphic artists of today's Austrian Social and Economic Museum were specifically told by journalists that the Isotype method was too complicated for today's readers. ${ }^{28}$ They would need too much time and too much attention to understand an Isotype graphic. It should be noted that Neurath was well aware that reading his pictograms required a degree of practice.- So what, then, is the advantage of the whole thing if it is not to provide people with information that can be grasped at a single glance?

Let us remind ourselves of Neurath's project for a renewed economic theory. He was looking for a method that would be capable of describing the life circumstance of an individual or population as the embodiment of quite disparate elements. Neurath was already advocating that size ratios should not be calculated in figures but represented symbolically instead. In his extensive critique of Wundt's Logik from 1910 he wrote:

Even Wundt, who after all does also consider exact logic and the parts of mathematics that do not deal with measurable quantities, does not indicate that the method of symbolic-exact representation and that of quantitative-exact representation do not have to coincide at all. ${ }^{29}$

Indeed, with the aid of symbols, it would be possible to compare heterogeneous entities precisely with one another without having to reduce their components to a uniform standard. Neurath made clear at the time what he had in mind by referring to the way in which pictures are compared.

One cannot compare two states by comparing them bit by bit, say first the constitution, then the climate etc.; each of them has to be comprehended as a whole. After all, neither can we compare pictures in this way, nor can we do this with respect to machines. The very idea of a calculus, however, consists of deriving a complex from the individual elements. ${ }^{30}$ 
Pictorial statistics provide a much clearer idea of what Neurath had in mind in this early text. For the comparisons that mattered to him to be carried out, the 'pictures' of the states that are to be compared have to be structured in a particular way. If we choose the first visualisation method (using squares), our judgements will have to be limited to form 'A is larger than ...'. To achieve greater precision, we would have to make a separate calculation. In this particular example that would be very easy to do (measure the sides of the squares, and calculate their surface areas and the difference between them). The calculation would end in a precise figure, namely the difference in surface area in $\mathrm{mm}^{2}$. The precision is, of course, obtained using a method that replaces our visually guided comparative judgement. In more complicated cases the calculation would have to be made by an expert, aided perhaps by a computer.

By contrast the visualisation method which Neurath advocated is based on an approach in which the added precision is achieved in quite a different way, namely by comparing back and forth between two constellations of elements. The contrasted constellations trigger certain activities in the observer: 'considerations' in which she constructs the comparison herself. What is important to note here is that the pictorial representation conceived by Neurath cannot by any means replace the language of words. On the contrary. It is only in the case of the visualisation method he rejected (in the case of squares or of pictures of different size) that we can grasp what the comparison says directly, as it were, without language, at a glance: larger - smaller. By contrast the Isotype pictures are constructed discursively. We cannot grasp what they represent through immediate 'intuition' (using a philosophical expression of long tradition), but only by 'going back and forth' and gradually uncovering what the comparison is about. This is shown very nicely in the chart on the automobile industry. (Picture 8)

Here we see at first glance that many more cars are manufactured in North and South America than in Europe. In a next step - by adding up how many people work in each car industry - we see that eleven times more cars are manufactured per worker in America than in Europe. And in a third step we find out how this enormous difference comes about: behind the workers in America we can make out the conveyor belt. So again: without putting what we see into words, we will not grasp what is represented in the pictures. But we can and must find our own words for that - ideally in discussions and conversations about what is shown, such as those which, according to Neurath, were often to 


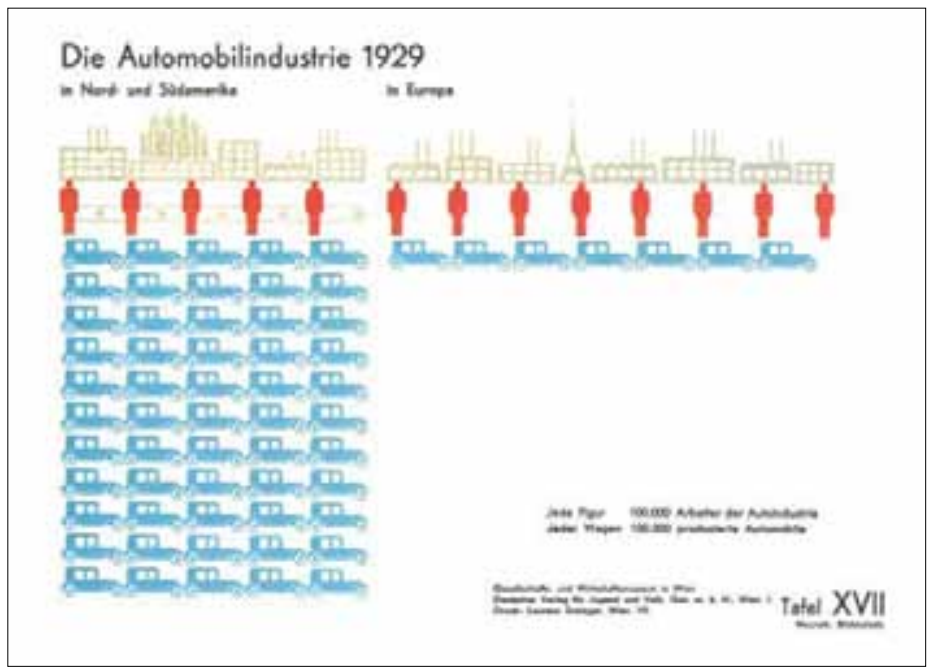

Picture 8.

be observed at the Social and Economic Museum. Neurath made many interesting observations about the educational implications of this experience and their significance in terms of democratic policy. But we cannot go into them here.

Here it is first and foremost a matter of understanding the Isotype method as an intellectual tool designed to make observers of the pictorial statistic charts perceive societies from a particular point of view: as collections of different elements of individual pleasure and displeasure, of life opportunities and restrictions that can be unevenly distributed within a group of individuals. The charts draw our attention to the fact that the distribution depends on factors that concern the whole of a population, a nation, a group, etc. However, the visualisation is structured in such a way that the individuals do not disappear within the whole to which they belong. ${ }^{31}$ On the contrary the observer has no option but to reconstruct a social whole, in each step of his comparison, as heterogeneous totalities of individual life circumstances. Through this means of visually guided judgement we experience the fact that what we see as the well-being of individuals and groups can vary sharply in scope and content depending on the point of view from which we consider them. And also that a great deal depends on the work and the imagination of those who seek to make societal facts visible. What those facts are will depend on which aspects of human life - and how many - they include in 
their observation, and what influencing factors they are seeking to address as a topic. ${ }^{32}$ In this process of visualisation of social facts it is by no means just social scientists, statisticians and graphic artists who are called upon. Observers, too, who are prepared to engage with the charts of pictorial statistics, so to speak as readers, will realise that deciphering the charts entails work and that the work involved frees up the imagination. If the charts are well made, they capture only a few aspects of a population's life circumstance and represent them in several constellations. Good pictorial statistics, according to Neurath, are limited to correlating a clearly demarcated set of contents for the purposes of mutual comparison. ${ }^{33}$ And it is precisely because the Isotype representation

Picture 9.

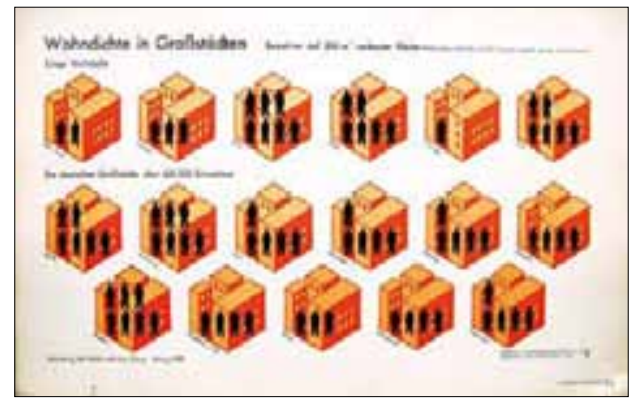

limits itself to representing only a few clearly defined data in correlation that it gives the observer something to think about. Here science does not emerge as the authoritative body that issues explanations and demands from non-scientists that they follow the explanations.

The question of which causes are responsible for the differences between the compared constellations is suggested whenever an Isotype chart is considered. In many cases it can be regarded as the key point of the entire comparison and fully imposes itself on the observer. Of course it is striking that, within the charts, the question of causal relationships is only rarely posited and answered explicitly - one of the examples in which this does happen is the conveyor belt at a car manufacturing plant (see picture 8). While in some charts the question of the causes does impose itself, it cannot be answered from the chart itself (e. g. the cycles of unemployment in picture 3). Some charts juxtapose size ratios where the question of a cause 


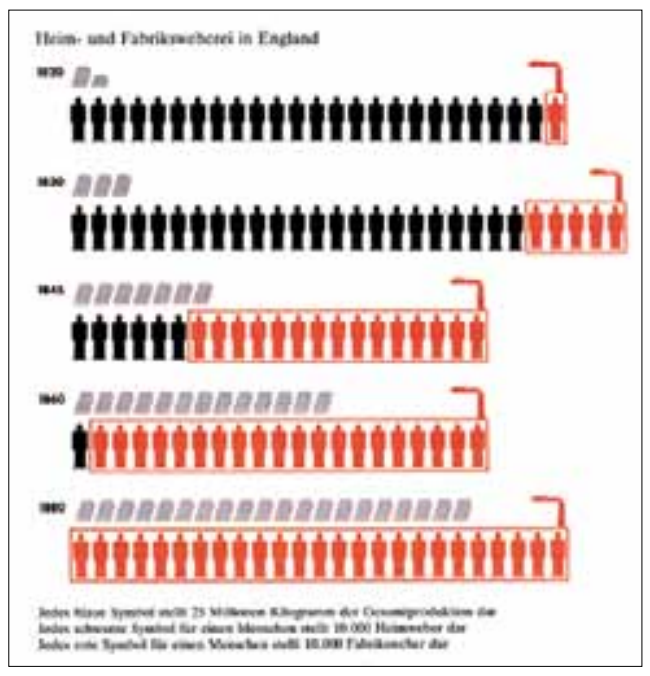

Picture 10.

barely seems relevant (e. g. the case of housing density in cities, picture 9); in others a dependence between sizes becomes visible for which a causal interpretation seems irrefutable (e. g. the chart on 'Home and factory weaving in England', picture 10). The fact that the representation using pictorial statistics usually leaves unanswered the way in which the dependency between the represented sizes is to be interpreted is anything but a coincidence or an omission. Rather, Neurath is following an agenda inspired once again by Ernst Mach: Mach believed that the concept of cause was an anthropomorphism that ought best to be eliminated from science altogether. Likewise the notion of the unity of science is one which Neurath borrowed directly from Mach. As Neurath wrote in 1945: 'The educational background for Visual Education is that of Unified Science. The Unity of Science Movement is really concerned with a common terminology and with replacing e. $\mathrm{g}$. a 'cause-effect' terminology by a 'grow-out-of' terminology'. ${ }^{34}$ It is perhaps worth mentioning that a line could be reconstructed here, leading from Ernst Mach to Neurath to today's widespread theories of 'emergence'.

Sometimes though, as in the chart on 'infant mortality in Vienna' (picture 11), our attention is actually drawn to a whole range of factors that has an impact on the level, composition and distribution of well-being within a population. But even in this case it is not about naming an individual cause for 
the distributions and the way in which they change. We are dealing here with a comparison in two dimensions: between the periods 1901 to 1905 and 1925 to 1929, and also between two municipal districts of Vienna. Each of the four pictures shows 20 babies, with several of them obscured by small coffins. They symbolise the children who died before reaching their first birthday. We see at first glance that, overall, the number of small coffins in the 1920s is dramatically smaller than at the beginning of the century: infant mortality fell by more than half in 20 years - a remarkable success story. We can imagine how the visitors at the Social and Economic Museum might have paused for thought and then wondered: what brought about this dramatic improvement? Hygiene measures, medicine, better nutrition? So while the picture raises the questions of the factors involved, it does not answer them. It focuses the attention on the second dimension of the comparison: the differences between the 'more affluent' and the 'poorer' districts of Vienna. Expressed in absolute figures, the drop in child mortality is the same in both districts: in both districts there are two small coffins fewer than in the years 1901-1905.

Picture 11.

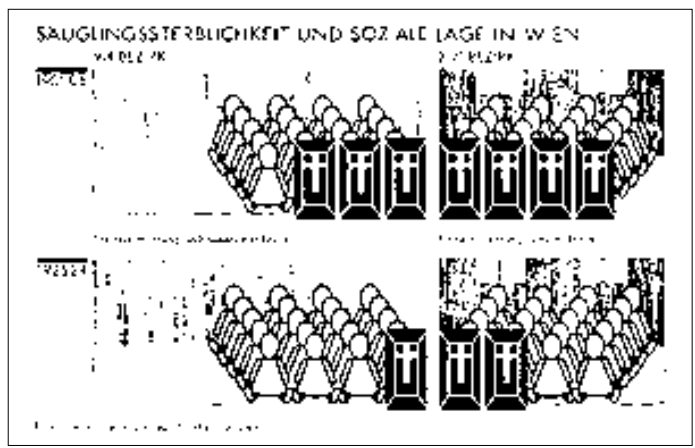

Of course for the wealthier 7th district that means a reduction of two thirds; for the poorer 16th district a reduction of only half. In the 1920s child mortality in the working-class district of Ottakring was still twice as high as in the middle-class district of Josefstadt. So how is it that both districts were able to benefit to such varying degrees from the overall improvement? The picture gives at least an indication of the answer to that question: the apartment in which the babies of the 7 th district are shown is one third bigger 
and considerably brighter than the one in the 16th district. This refers to the serious housing problem that existed in Vienna between the two World Wars, and the enormous building activity undertaken by the Municipality of Vienna in the 1920s. And yet this pointer can hardly be misunderstood as a monocausal explanation. It draws attention to the 'institutions and measures' that can be taken and are indeed taken. Here again we can well imagine the visitors of the Social and Economic Museum wondering and saying to themselves: the larger, airier apartments are one thing - but isn't medical care just as important? Or setting up nurseries? Maternal health care? and so on and so forth.

In a genuinely scientific museum it could never be a matter, from Neurath's point of view, of proclaiming certain answers as the only right answers. $\mathrm{He}$ devoted a lifetime to combating 'pseudorationalism', which elevates science to the pedestal of a quasi-religious body. Entirely in the tradition of Ernst Mach, Neurath regarded it as the task of science to describe relations between phenomena. And like Mach he was of the opinion that our view of the connections is often obscured by our own traditional concepts. For Mach, science was not just an instrument of enlightenment, but also an 'enlightening' activity par excellence. As mentioned earlier, for Mach scientific progress is based on nothing other than the ability and the willingness of researchers to keep seeing through their previous concepts and theories as auxiliary structures. ${ }^{35}$ What for Mach as a natural scientist was the progressive value of science in general had a direct political significance for the sociologist and economist Neurath. For Neurath, introducing a scientific approach in the Machian sense to social theory meant developing an approach that highlights connections that would otherwise remain unnoticed as long as there is talk of the 'nation', the 'people' or the 'class' as a whole. It very much takes these entities into account, but considers them as a group of individuals whose life circumstances are characterised by a set of elements whose distribution depends on political, economic, cultural ... measures and institutions. The project of making this artificially naive, scientific approach accessible to as many people as possible using visual education meant nothing other than an attempt to create the social preconditions for a discourse in which the issue of the political shaping of the social order in a rational way figures as a topic.

In one of his last writings Neurath once again emphasised the political dimension of this project. He wrote that visual education was not aimed first and foremost at imparting knowledge, but at passing on a 'scientific 
attitude', adding that such an attitude was essential to the further development of democratic societies.

Education is not only the handing on of knowledge, it is also concerned with the ability to analyze observations and to find out something and contemplate all the matter under discussion from all sides. [...] The transfer of looking at more than one possibility, to be prepared to alter statements, is the principle of the scientific attitude. The social pattern, which permits more than one opinion etc. is the 'democratic pattern'. Part of education deals with the evolution of one's own judgment, of a 'scientific attitude', a quality not restricted to scholars only; there are laymen who have it, and there are scientists who do not have it. ${ }^{36}$

\section{Notes}

* This article is a revised version of 'Wissenschaftliche Haltung und Bildersprache. Otto Neurath zur Visualisierung in den Sozialwissenschaften.' Tabellen, Kurven, Piktogramme. Techniken der Visualisierung in den Sozialwissenschaften. Vol. 1-2 of Mitteilungen des Instituts fuer Wissenschaft und Kunst: 31-42. The text was translated by Stephen Grynwasser and Naomi Osorio-Kupferblum.

1 An undated letter (probably from 1915) from Otto Neurath to Ernst Mach, Engl. transl. in Blackmore et al. (eds.) 2001, Dordrecht: Kluwer, 117-118.

2 On this and on Neurath's biography see: Neurath 1973, Paul Neurath 1994, Cartwright, Cat, Fleck, Uebel 1996, Stadler 2001, Uebel 2005b, Cat 2010.

3 Uebel 2004 gives an excellent, comprehensive analysis of Neurath's economic thought.

4 Neurath (1909) 2004, 292-296. See also Uebel 2004 and 2007.

5 See also various examples: Martinez-Alier 1987, O’Neill 1993, 1998, 1999, 2007, Nemeth and Heinrich (eds.) 1999, Uebel 2004, 2005a, 2007b, Lessmann 2007a and 2007b, Nemeth, Schmitz, Uebel (eds.) 2007.

6 Neurath 1911, reprinted in Neurath 1998, 470-518. Unfortunately this version of the article contains several errors. I therefore decided to use the original text from 1911. All the following quotations from Neurath 1911 were translated by Stephen Grynwasser and Naomi Osorio-Kupferblum.

7 Neurath 1911, 53.

8 Neurath (1910) 2004, 272.

9 Contemporary poverty research speaks of the 'multi-dimensionality' of poverty 
and wealth (cf. Lessmann 2007a and b), and ecological economics of the 'incommensurability of values' (cf. Uebel 2005a, $319 \mathrm{f}$.).

10 In italics in the original. Neurath 1911, p. 80.

11 Neurath 1911, 78.

12 Neurath 1911, 79.

13 Neurath 1911, 80.

14 Neurath 1911, 80.

15 I have expounded and substantiated what follows in greater detail in Nemeth 2007.

16 Mach (1905, 1926) 1991, 14, All the following quotations from Mach (1905, 1926) 1991 were translated by Stephen Grynwasser and Naomi Osorio-Kupferblum.

17 Mach (1905, 1926) 1991, 14.

$18 \operatorname{Mach}(1905,1926) 1991,14$.

19 Mach $(1905,1926) 1991,16-17$.

20 Mach (1905, 1926) 1991, 8.

21 Incidentally, there is an affinity here to Bachelard, Foucault and also Bourdieu.

22 Neurath (1945) 1996, 257.

23 Neurath (1945) 1996, 257.

24 Twyman 1975 and 1985, Kinross 1981, 1984, Stadler (ed.) 1982, Mueller 1991, Nemeth and Stadler (eds.) 1996, Leonard 2001, Stadler 2002, Hartmann and Bauer 2002, Moravian Gallery 2002, Behnke et al. 2004, Hartmann 2005, Blau 2006, Mertens 2007, Kraeutler 2008, Vossoughian 2008, Neurath Marie and Kinross 2009, Burke 2009, 2010a, Nemeth forthcoming. I want to draw special attention to the edition of a manuscript of the late Neurath which has not been published until 2010: From hieroglyphics to Isotype (see Neurath 2010) and to the excellent introduction by C. Burke (Burke 2010b). The volume includes the numerous illustrations intended by Neurath to accompany his text, and is completed by an extensive appendix showing examples from the rich variety of graphic material that he collected.

25 Neurath (1936) 1980, 23.

26 Hartmann 2002, 49.

27 The example in the figure is taken from Tufte 2001, 69, who by the way makes no mention whatsoever of Neurath in his other books on the visualisation theory.

28 In a personal discussion following a lecture at the Austrian Museum for Social and Economic Affairs.

29 Neurath (1910) 2004, 277.

30 Neurath (1910) 2004, 280.

31 For the relationship between holism and individualism in Neurath's thoughts on 
economics and how it impacts the Isotype method, see Nemeth 2003 and 2006.

32 We should refer here to the strong affinity between Neurath's project and Martha Nussbaum's works in the 1990s. See in particular Nussbaum and Sen, eds., 1993. Thoughts on this affinity can also be found in Nemeth 2003 and 2006.

33 That is the point in Neurath's repeated insistence that a picture should not contain more information than can be grasped in three glances. See the quotation in note 24 .

34 Neurath (1945) 1996, 259.

35 See: Uebel 2000, 93-95.

36 Neurath (1945) 1996, 260.

\section{Literature}

Behnke, Christoph, D. Stoller, A. Schlosser and U. Wuggenig, eds. 2004. Atlas. Spaces in subjunctive. Lüneburg: Verlag für Wissenschaft und zeitgenössische Kunst.

Blackmore, John, ed. 2001. Ernst Mach's Vienna 1895-1930 or Phenomenalism as Philosophy of Science, Boston Studies in the Philosophy of Science 218. Dordrecht: Kluwer.

Blau, Eve. 2006. 'Isotype and Architecture in Red Vienna. The Modern Projects of Otto Neurath and Josef Frank.' Austrian Studies 14: 227-259.

Burke, Christopher. 2009. 'Isotype. Representing social facts pictorially.' Information Design fournal 17/3: 210-221.

Burke, Christopher. 2010a. 'Back to basics: Otto Neurath and Isotype.' Cambridge Literary Review 1/3: 221-235.

Burke, Christopher. 2010b. Introduction to Neurath 2010: vii-xvi.

Cartwright, Nancy, Jordi Cat, Lola Fleck and Thomas E. Uebel. 1996. Otto Neurath: Philosophy between Science and Politics. Cambridge: Cambridge University Press

Cat, Jordi. 2010. 'Otto Neurath.' Stanford Encyclopedia of Philosophy. http://plato. stanford.edu/entries/neurath/

Hartmann, Frank and Erwin K. Bauer. 2002. Bildersprache, Otto Neurath, Visualisierungen. Wien: Wiener Universitätsverlag.

Hartmann, Frank. 2005. 'Humanization of Knowledge through the Eye.', in Making Things Public - Atmospheres of Democracy, edited by Bruno Latour and Peter Weibel, 698-707. Karlsruhe, Germany: MIT Press and ZKM.

Kinross, Robin. 1981. 'On the influence of Isotype.' Information Design Fournal 2/21: $122-130$. 
Kinross, Robin. 1984. 'The work of Otto Neurath in visual communication.' Fundamentum Scientic 5/2: 185-99.

Kraeutler, Hadwig. 2008. Otto Neurath. Museum and Exhibition Work. Spaces (Designed) for Communication. Frankfurt am Main: Peter Lang.

Leonard, Robert J. 2001. "'Seeing Is Believing” Otto Neurath, Graphic Art, and Social Order.' History of Political Economy. Special Supplement. 31: 452-47.

Lessmann, Ortrud. 2007a. Konzeption und Erfassung von Armut. Vergleich des LebenslageAnsatzes mit Sens 'Capability'-Ansatz. Berlin: Duncker und Humblot.

Lessmann, Ortrud. 2007b. 'A Similar Line of Thought in Neurath and Sen: Interpersonal Comparability.' In Nemeth, Schmitz, Uebel, eds., 115-130.

Mach, Ernst. (1905) 1991. Erkenntnis und Irrtum. Skizzen zur Psychologie der Forschung. Darmstadt: Wissenschaftliche Buchgesellschaft.

Martinez-Alier, Joan. 1987. Ecological Economics. Energy, Environment and Society. London: Blackwell.

Mertens, Ferdinand. 2007. 'Een Wereld - Verbeteraar', in Den Haag. De Haagse Ballingschap van Otto Neurath. The Hague: Gemeente Den Haag.

Moravian Gallery in Brno. 2002. - a vývoj modernich globálńch znaku, - and the development of modern global signs, Edition Designrevue Cz. Prague: Alba Studio.

Mueller, Karl H. 1991. 'Neurath's Theory of Pictorial-Statistical Representation.' In Thomas E. Uebel, ed., 223-254.

Nemeth, Elisabeth and Friedrich Stadler, eds. 1996. Encyclopedia and Utopia. The Life and Work of Otto Neurath (1882-1945), Vienna Circle Institute Yearbook 4/96. Dordrecht: Kluwer.

Nemeth, Elisabeth and Richard Heinrich, eds. 1999. Otto Neurath: Rationalität, Planung, Vielfalt. Wiener Reihe 9. Wien-Berlin: Oldenbourg/Akademie.

Nemeth, Elisabeth, Stefan W. Schmitz and Thomas E. Uebel, eds. 2007. Otto Neurath's Economics in Context. Vienna Circle Institute Yearbook 13/07. Springer.

Nemeth, Elisabeth. 2003. 'Gesellschaftliche Tatbestände sichtbar machen. Otto Neurath über den Gegenstand der Wirtschaftswissenschaft und seine Visualisierung.' In Philosophie an der Schwelle des 21. Jahrhunderts, edited by Ewa CzerwinskaSchupp, 181-207. Frankfurt a. M.: Lang.

Nemeth, Elisabeth. 2006. 'Socially Enlightened Science. Neurath on Social Science and Visual Education.' In Thèmes de Philosophie Analytique, ed. by Mélika Ouelbani, 83-112. Tunis.

Nemeth, Elisabeth 2007. "Freeing up One's Point of View". Neurath's Machian Heritage Compared with Schumpeter's.' In Nemeth, Schmitz, Uebel, eds., $13-36$. 
Nemeth, Elisabeth. Forthcoming. 'Visualising relations in society and economics. Otto Neurath's Isotype-method against the background of his economic thought.' In Pointure du Symbole, edited by Jean-Yves Beziau. Paris: editions Petra.

Neurath, Marie and Robin Kinross. 2009. The transformer. Principles of making Isotype charts. London: Hyphen Press.

Neurath, Otto. (1909) 2004. 'Diskussionsbeitrag ueber die Produktivitaet des Geldes', translated as 'Remarks on the Productivity of Money.' In Neurath 2004, 292-296.

Neurath, Otto. (1910) 2004. 'Zur Theorie der Sozialwissenschaften', translated as 'On the Theory of Social Science.' In Neurath 2004, 265-291.

Neurath, Otto (1911) 1998. 'Nationalökonomie und Wertlehre, eine systematische Untersuchung.' Zeitschrift für Volkswirtschaft, Sozialpolitik und Verwaltung 20: 52-114. Reprinted in Neurath 1998, 470-518.

Neurath, Otto. (1936) 1980: International picture language/Internationale Bildersprache. A facsimile reprint of the [1936] English edition with a German translation by Marie Neurath, published by the Department of Typography \& Graphic Communication at the University of Reading.

Neurath, Otto (1945a) 1973. 'From Vienna Method to Isotype.' In Neurath 1973, 214-284.

Neurath, Otto (1945b) 1996. 'Visual Education. Humanisation versus Popularisation' edited by Juha Manninen. In E. Nemeth and F. Stadler, eds. 1996, 245-335.

Neurath, Otto. 1973: Empiricism and Sociology, edited by Marie Neurath and Robert S. Cohen, Dordrecht: Reidel.

Neurath, Otto. 1981: Gesammelte philosophische und methodologische Schriften (= Gesammelte Schriften 1 and 2), edited by Rudolf Haller and Heiner Rutte. Vienna: HölderPichler-Tempsky.

Neurath, Otto. 1991: Gesammelte bildpädagogische Schriften (= Gesammelte Schriften 3), edited by Rudolf Haller and Robert Kinross. Vienna: Hölder-Pichler-Tempsky.

Neurath, Otto. 1998. Gesammelte ökonomische, soziologische und sozialpolitische Schriften (= Gesammelte Schriften 4 and 5), edited by Rudolf Haller and Ulf Höfer. Vienna: Hölder-Pichler-Tempsky.

Neurath, Otto. 2004. Economic Writings. Selecions 1904-1945, ed. by Thomas E. Uebel and Robert S. Cohen. Vienna Circle Collection 23. Dordrecht: Kluwer

Neurath, Otto. 2010. From hieroglyphics to Isotype. A visual autobiography, ed. by Matthew Eve and Christopher Burke. London: Hyphen Press

Neurath, Paul and Elisabeth Nemeth, eds. 1994. Otto Neurath oder Die Einheit von Wissenschaft und Gesellschaft. Vienna/Cologne/Weimar: Böhlau 
Neurath, Paul. 1994. 'Otto Neurath (1882-1945). Leben und Werk.' In: Paul Neurath and Elisabeth Nemeth, eds., 13-96.

Nussbaum, Martha and Amartya Sen, eds. 1993. The Quality of Life. A Study prepared for the World Institute for Development Economics Research (WIDER) of the United Nations University. Oxford: Clarendon.

O’Neill, John. 1993. Ecology, Policy and Politics: Human Well-Being and the Natural World. London: Routledge.

O’Neill, John. 1998. The Market. Ethics, Knowledge and Politics. London/New York 1998.

O’Neill, John. 1999. 'Socialism, Ecology and Austrian Economics.' In Nemeth, Heinrich, eds., 123-145.

O’Neill, John. 2007. 'Pluralism and Economic Institutions.' In Nemeth, Schmitz, Uebel, eds., 77-100.

Stadler, Friedrich, ed. 1982. Arbeiterbildung in der Zwischenkriegszeit. Otto Neurath, Gerd Arntz. Ausstellungskatalog mit Forschungsteil. Vienna/Munich: Löcker.

Stadler, Friedrich. 2001. Studies on the Vienna Circle. Vienna/New York: Springer.

Stadler, Friedrich. 2002. 'Schriftsprache und Bildsprache nach Otto Neurath Popularisierung oder Humanisierung der Wissenschaft?' In: Wissenschaft, Politik und Öffentlichkeit von der Wiener Moderne bis zur Gegenwart, edited by Mitchell Ash and Christian Stifter, 267-303, Vienna.

Tufte, Edward. 2001. The Visual Display of Quantitative Information. Cheshire: Graphics Press.

Twyman, Michael. 1975. 'The significance of Isotype.' http://www.isotyperevisited. org/1975/01/the-significance-of-isotype.html

Twyman, Michael. 1985. 'Using Pictorial Language: A Discussion of the Dimensions of the Problem.' In Designing Usable Texts, edited by Thomas Duffy and Robert Walker. Orlando: Academic Press.

Uebel, Thomas E. 2000. Vernunftkritik und Wissenschaft. Otto Neurath und der erste Wiener Kreis im Diskurs der Moderne. Publications of the Vienna Circle Institute 9. Vienna/ New York: Springer.

Uebel, Thomas E. 2004. 'Neurath's Economics in Critical Context.' In Otto Neurath 2004, 1-108.

Uebel, Thomas E. 2005a. 'Incommensurability, Ecology, and Planning. Neurath in the Socialist Calculation Debate, 1919-1928.' History of Political Economy 37/2: 309-342.

Uebel, Thomas E. 2005b. 'Otto Neurath. Leben und Werk.' In Internationale Bibliographie zur österreichischen Philosophie. Bearbeitet von T. Binder, R. Fabian, U. Höfer, J. Valent, 7-51. Amsterdam/New York: Rodopi. 
Uebel, Thomas E. 2007. 'Otto Neurath as an Austrian Economist: Behind the Scenes of the Early Socialist Calculation Debate.' In Nemeth, Schmitz, Uebel, eds., $37-60$.

Uebel, Thomas E., ed. 1991. Rediscovering the Forgotten Vienna Circle. Boston Studies in the Philosophy of Science. Amsterdam: Kluwer.

Vossoughian, Nader. 2008. Otto Neurath. The Language of the Global Polis. Rotterdam: NAi publishers.

\section{Picture Credits}

Picture 6 shows page 69 of Edward R. Tufte's The Visual Display of Quantitative Information (Cheshire: Graphics Press). His two examples of confusing statistics are taken from R. Satet, Les Graphiques (Paris 1932, p. 12) and the Los Angeles Times (August 5, 1979, p. 3).

Picture 7, the chart on Visualisation Methods, is taken from the 1980 bilingual facsimile reprint: Otto Neurath: International picture language/Internationale Bildersprache [1936]. Edited by Robin Kinross. Reading: University of Reading, Department of Typography \& Graphic Communication 1980.

All other images are taken from: Otto Neurath: Gesammelte bildpädagogische Schriften (Gesammelte Schriften Band 3), eds. Rudolf Haller and Robin Kinross, Vienna: Hölder-Pichler-Tempsky 1991. 
